\title{
Multidisciplinary, evidence-based consensus guidelines for human papillomavirus (HPV) vaccination in high- risk populations, Spain, 2016
}

Xavier Martínez-Gómez ${ }^{1}$, Adrian Curran², Magda Campins ${ }^{1}$, Laia Alemany³ , José Ángel Rodrigo-Pendás ${ }^{1}$, Natalia Borruel ${ }^{4}$, Xavier $^{2}$

Castellsagué ${ }^{3}$, Cristina Díaz-de-Heredia ${ }^{5}$, Fernando A Moraga-Llop ${ }^{6}$, Marta del Pino ${ }^{7,8}$, Aureli Torné $e^{7,8}$

1. Servei de Medicina Preventiva i Epidemiologia, Hospital Universitari Vall d'Hebron - Universitat Autònoma de Barcelona, Barcelona, España

2. Servei de Malalties Infeccioses, Hospital Universitari Vall d’Hebron - Universitat Autònoma de Barcelona, Barcelona, España

3. Programa de Recerca en Epidemiologia del Càncer, Institut Català d’Oncologia - IDIBELL CIBER Epidemiología y Salud Pública, Barcelona, España

4. Unitat d'Atenció Crohn-Colitis, Servei d’Aparell Digestiu; Hospital Universitari Vall d'Hebron - Universitat Autònoma de Barcelona, Barcelona, España

5. Servei d’Oncologia i Hematologia Pediàtrica, Hospital Universitari Vall d’Hebron - Universitat Autònoma de Barcelona, Barcelona, España

6. Asociación Española de Vacunología, Barcelona, España

7. Unidad de Ginecología Oncológica, Instituto Clínico de Ginecología y Obstetricia y Neonatología (ICGON), Hospital Clínic de Barcelona, Barcelona, España

8. Instituto de Investigaciones Biomédicas August Pi i Sunyer (IDIBAPS), Facultad de Medicina, Universidad de Barcelona, Barcelona, España

Correspondence: Magda Campins (mcampins@vhebron.net)

Martínez-Gómez Xavier, Curran Adrian, Campins Magda, Alemany Laia, Rodrigo-Pendás José Ángel, Borruel Natalia, Castellsagué Xavier, Díaz-de-Heredia Cristina, Moraga-Llop Fernando A, del Pino Marta, Torné Aureli. Multidisciplinary, evidence-based consensus guidelines for human papilloma virus (HPV) vaccination in high-risk populations, Spain 2016. Euro Surveill. 2019;24(7):pii=1700857. https://doi.org/10.2807/1560-7917.ES.2019.24.7.1700857

Introduction: Although human papillomavirus (HPV) routine vaccination programmes have been implemented around the world and recommendations have been expanded to include other high-risk individuals, current recommendations often differ between countries in Europe, as well as worldwide. Aim: To find and summarise the best available evidence of HPV vaccination in high-risk patients aiding clinicians and public health workers in the day-to-day vaccine decisions relating to HPV in Spain. Methods: We conducted a systematic review of the immunogenicity, safety and efficacy/effectiveness of HPV vaccination in high-risk populations between January 2006 and June 2016. HPV vaccination recommendations were established with levels of evidence according to the Grading of Recommendations Assessment, Development and Evaluation (GRADE) system. Results: A strong recommendation about HPV vaccination was made in the following groups: HIV infected patients aged 9-26 years; men who have sex with men aged 9-26 years; women with precancerous cervical lesions; patients with congenital bone marrow failure syndrome; women who have received a solid organ transplant or hematopoietic stem cell transplantation aged 9-26 years; and patients diagnosed with recurrent respiratory papillomatosis. Conclusions: Data concerning non-routine HPV vaccination in populations with a high risk of HPV infection and associated lesions were scarce. We have developed a document to evaluate and establish evidence-based guidelines on HPV vaccination in highrisk populations in Spain, based on best available scientific evidence.

\section{Introduction}

Human papillomavirus (HPV) is the main cause of uterine cervical cancer (UCC) and its precursor lesions $[1,2]$. HPV can also be found in cancerous and precancerous lesions of the vulva and vagina [3,4], penis [5] anus [6], oropharyngeal cancer [7], anogenital warts [8] and recurrent respiratory papillomatosis (RRP) [9]. Nearly $90 \%$ of all female genital HPV infections are transient and resolve on their own in the next 2 years [10]. Persistence of HPV happens in $10 \%$ of infected healthy women and $1 \%$ of them will develop neoplastic HPV-related lesions. In men, duration and persistence of HPV infections are shorter than in women [11].

The estimated impact of newly diagnosed cases of HPV-related disease is high around the world: annually there are 30.9 million cases of cervical precancerous lesions, 32 million cases of genital condylomata and 630,000 cases of cancer (cervix, vagina, vulva, anus, penis, oropharyngeal, oral cavity and larynx) diagnosed $[12,13]$. 


\section{Box}

Individuals at high risk of human papillomavirus infection and related diseases, Spain, January 2006-June 2016

- HIV infected patients

- MSM

- Inflammatory bowel disease patients

- Women with precancerous cervical lesions

- Patients with congenital bone marrow failure syndrome, primary immunodeficiency or survivors of childhood neoplasia

- Solid organ or haematopoietic stem cell transplant recipients

- Patients with immunosuppressive or biological treatment

- Patients with recurrent respiratory papillomatosis

HIV: Human immunodeficiency virus; HPV: human papillomavirus; MSM: men who have sex with men.

HPV vaccination is an effective primary intervention to prevent HPV infection and its associated disease burden. Vaccination is used as part of a coordinated strategy with quality screening programmes and treatment services in cervical cancer prevention [14]. Three HPV vaccines containing virus-like particles (VLPs) are currently available: the bivalent vaccine (VLPs of high-risk HPV genotypes 16 and 18) [15]; the quadrivalent vaccine (VLPs of genotypes 6, 11, 16 and 18) [16]; and the nonavalent vaccine (VLPs of genotypes $6,11,16,18$, $31,33,45,52$ and 58) [17].

In the first decade of HPV vaccine use, the main strategy worldwide was routine vaccination programmes for adolescent and young women. In Europe, according European Centre for Disease Control (ECDC) information reviewed in 2018 , routine vaccination is included in the national immunisation schedule in the majority of countries ( $n=29,93.5 \%$ ) [18]. In some countries, vaccine recommendations were later extended to include specific high-risk groups as the United States (US) where three doses of HPV vaccine are recommended for: (i) females and males aged 9-26 years with primary or secondary immunocompromising conditions that may reduce cell-mediated or humoral immunity, (ii) men who have sex with other men (MSM), (iii) transgender persons aged 9-26 years, (iv) individuals not adequately vaccinated and, (v) children with a history of sexual abuse $[19,20]$. In Australia MSM and immunocompromised individuals are included [21] and in Canada individuals with abnormal cervical cytology or a history of UCC and/or genital warts, MSM and immunocompromised individuals [22] are included too. Currently, no global European recommendations for specific groups are mentioned [18] but some countries have begun to develop programmes [23].

In clinical practice, there is growing interest in expanding vaccine recommendations to patients at high-risk of HPV infection and development of related neoplasms. Currently, information on HPV vaccination for these high-risk populations is scarce and recommendations for selective vaccination differ between countries in Europe. Several reasons may explain the lack of guidelines for vaccination in high-risk populations, including: heterogeneity in the definition e.g. age, sex, disease characteristics and variations in the risk of infection, persistence or malignancy; limited published clinical trial data (due to difficulties in conducting appropriately powered studies on vaccine immunogenicity, safety and efficacy in individuals with low-incidence diseases); and limitations associated with establishing recommendations for patient groups not included in the product label. Some of these issues can be viewed in the Supplementary material.

A guideline on HPV vaccination in high-risk individuals, based on the review of current evidence by an independent and multidisciplinary expert panel, was recently released by the Spanish Association of Cervical Pathology and Colposcopy [24]. This paper summarises this evidence-base and process and depicts the guideline.

\section{Methods}

In October 2015, a steering committee was formed in Spain to compile this guideline after a rigorous review of the HPV-associated disease burden and a systematic review of studies investigating the immunogenicity, safety and efficacy of HPV vaccination in high-risk populations. This committee consisted of 10 Spanish professionals including gynaecologists, epidemiologists, paediatricians, infectologists, haematologists, gastroenterologists and preventive medicine specialists with recognised expertise in the area.

\section{Selection criteria}

This review included both randomised controlled trials (RCT) and observational studies (e.g. cohort studies, case reports) that assessed the effects of HPV vaccination on high-risk groups.

Based on clinical expertise of the steering committee and published literature, the following groups were defined as individuals at high-risk of HPV infection and HPV-related disease and were included in the guideline on HPV vaccination in high-risk individuals (Box).

The interventions of interest were the bivalent (Cervarix), quadrivalent (Gardasil) and nonavalent (Gardasil 9) HPV vaccines. The outcomes of interest were the efficacy, effectiveness, immunogenicity and safety of HPV vaccines.

Studies that did not report original data e.g. editorials or reviews were excluded. 


\section{FIGURE}

Flowchart of literature selection for review of human papillomavirus vaccination in high-risk populations, Spain, January 2006-June 2016

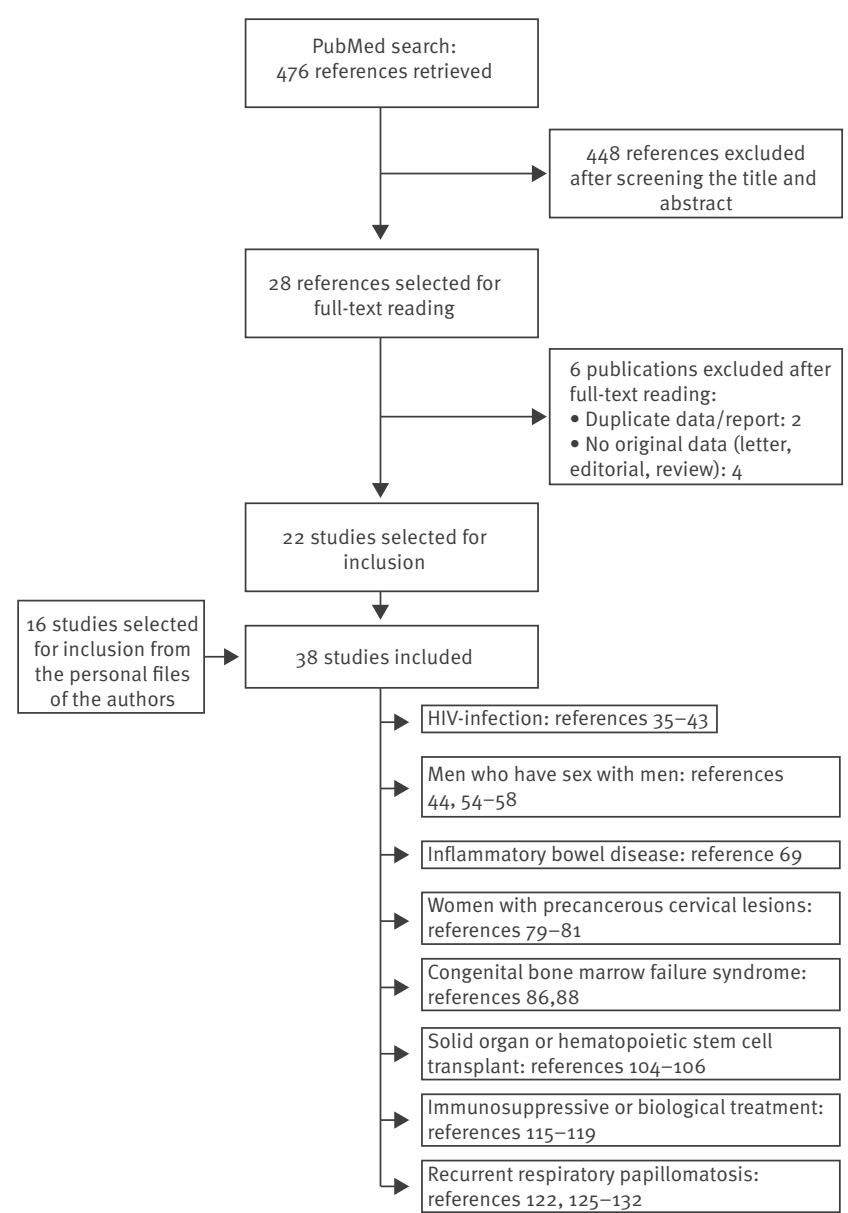

HIV: Human immunodeficiency virus.

\section{Search strategy}

An electronic search was carried out using PubMed to find studies published in English from January 2006 to June 2016 . The search terms were a combination of the names and synonyms of the different risk groups, the HPV vaccines and the outcomes of interest. The details of the search strategies are presented in the Supplementary material.

All authors conducted unstructured electronic searches and reviewed their personal files for relevant published papers.

\section{Selection process}

Two authors (XMG and JARP) independently screened the titles and abstracts of the articles identified by the PubMed search and selected articles for full-text reading in accordance with the selection criteria. Full texts for the relevant references were independently evaluated by XMG and JARP to determine their inclusion. Reference lists of included articles were screened to consider further potentially eligible studies (Figure). Any discrepancies in study selection were resolved by discussion between the reviewers until a consensus was reached.

The agreement between reviewers in the selection process was computed using Stata/SE 14.2 for Windows (StataCorp LLC, College Station, Texas) and resulted in agreement of qualitative measures (Cohen's Kappa $=0.98)[25]$.

Panel subgroups reviewed the initial literature search, selected references, evaluated evidence, drafted recommendations and summarised the evidence for each section. The content of the guideline was decided by the consensus panel; the evidence evaluation process involved a systematic weighting of the quality of evidence and the grade of recommendation using the Infectious Diseases Society of America (IDSA) version of the Grading of Recommendations Assessment, Development and Evaluation (GRADE) system [26,27].

The developed guideline for Spain was reviewed and endorsed by several groups acknowledged at the end of the article.

\section{Results}

\section{Human immunodeficiency virus (HIV) infection}

The prevalence of HPV infection in individuals with HIV infection is high [28-30]. Within this population, the number of sexual partners increases the risk of infection and reinfection for multiple HPV genotypes and decreases the probability of HPV clearance [29]. Compared with the general population, the persistence of HPV in people living with HIV significantly increases the risk of HPV-related cancers and condylomata.

Three risk subgroups can be identified in the overall HIV-infected population: HIV-infected women, HIVinfected men who have sex exclusively with women (MSW) and HIV-infected MSM. While UCC screening programmes and the improvement in HIV disease control have led to a decrease in the incidence of UCC in HIV-infected women, the incidence of anal cancer in this population is 30 per 100,000 person-years (US, 1996-2007) [31], and the prevalence of condylomata is $5-7 \%$ vs $1 \%$ in the general population (US, 1991-1998) $[32,33]$. In line with this, HIV-infected MSW in the US during 1996-2007 have an incidence of anal cancer that was significantly higher compared with men without HIV infection (46 vs two/100,00o person-years) [31]. The prevalence of condylomata in HIV-infected MSW in Spain from 2005 to 2009 was 15\% [34]. The incidence of anal cancer in the US during 1996-2007 is especially high in MSM with HIV (131/100,000 person-years; rate ratio $=80.3$ compared with men without HIV) [31], and the prevalence of condylomata in HIV-infected MSM in Spain from 2005 to 2009 was $28 \%$ [34]. 
Rationale for recommendations

Nine papers of HPV vaccination in HIV population were selected [35-43]. Available data on the immunogenicity and safety of HPV vaccines in people with HIV infection support its use for the prevention of HPV-related cancers and genital warts; however, there are limited data on the efficacy of the vaccine (Supplementary material Table S1).

The efficacy results obtained in RCT of MSM [44] cannot be generalised to the HIV population, since the characteristics of the included individuals (age 16-26 years; $\leq 5$ lifetime sexual partners; no history of sexually transmitted infections) differ from the majority of MSM with HIV seen in clinical practice. Prospective, RCT evaluating the efficacy of HPV vaccines in the prevention of recurrence in people with HIV receiving treatment for condylomata or premalignant lesions are ongoing [45-47].

Ideally, people with HIV who receive a HPV vaccine should be on antiretroviral treatment and have good immune-virological control at the time of vaccination.

Summary of previous guidelines or consensus recommendations

The European Acquired Immune Deficiency Syndrome (AIDS) Clinical Society guidelines recommend HPV vaccination in all individuals with HIV; however, they state that in situations where there is an established HPV infection, vaccine efficacy is questionable [48]. The US guidelines recommend vaccination for HIV females and males through age 26 years $[19,20,49]$.

The 2013 IDSA clinical practice guideline for vaccination of the immunocompromised host, recommends the administration of three-dose of quadrivalent HPV (qHPV) vaccine for females and males with HIV aged $11-26$ years [27].

\section{Recommendations in HIV patients}

HPV vaccination is recommended in both male and female individuals with HIV from 9-26 years (quality of evidence: moderate; recommendation: strong). HIVpositive people aged 26 years and older could also benefit from HPV vaccination (quality of evidence low; recommendation: weak). The use of any of the available vaccines is indicated, although the quadrivalent or nonavalent vaccines are preferred given the high prevalence of anogenital warts in these patients.

\section{Men who have sex with men}

MSM have a high risk of HPV infection and HPV-related disease than MSW [50], with the incidence of anal neoplasia being nearly 20 times higher in MSM [51]. The annual recurrence rate of high-grade anal lesions following treatment may be up to $50 \%$ [52]. Data from the US suggest that MSM have a higher rate of condyloma than women do, but a lower rate than MSW [53].
Rationale for recommendations

Six papers of HPV vaccination in MSM population were selected (Supplementary material Table S2). One study evaluated the immunogenicity, efficacy and safety of the qHPV vaccine against HPV in healthy males aged 16-26 years [54]. Of the 4,065 men enrolled in the study, 602 were MSM. Antibody GMTs were lower in MSM vs MSW [55]. In MSM, the efficacy of the vaccine for prevention of persistent genital infection by any of the genotypes in the vaccine was $43.6 \%$, while the efficacy for the prevention of persistent anal infection by HPV 6, 11,16 or 18 was $94.9 \%$ [44,54]. The vaccine was effective in preventing $77.5 \%$ of the high-grade squamous intraepithelial lesions (HSIL)/anal intraepithelial neoplasia (AIN) secondary to HPV $6,11,16$ or 18 , and $70.2 \%$ of the genital warts [44].

The qHPV vaccine has also been evaluated in MSM patients aged 26 years or older. It was effective in the prevention of anal condyloma in a study of 313 MSM without story of anal condyloma or with history of previous HPV-related anal condyloma who had been recurrence-free for at least 12 months (hazard ratio $=0.45$; $\mathrm{p}<0.05$ ) [56]; it also reduced the incidence of HSIL (AIN) in another study of 202 MSM aged 18 years and older (83.7\% of themaged over30 years) who were treated for histologically confirmed HSIL (AIN) [57]. The recurrence rate of HSIL (AIN) in vaccinated MSM vs those not vaccinated was 10.2 vS 15.7 per 100 person-years [57].

One study assessed the immunogenicity and safety of the nonavalent vaccine vs placebo [58]. This trial included 313 MSM aged 16-26 years in addition to 1,106 MSW and 1,101 women who had neither received previous HPV vaccination nor had history of HPVrelated lesions. The per-protocol analysis showed that, in MSM, the seroconversion rate for different HPV types was 99.5-100\%; the GMTs in MSM were lower compared with MSW and women (ratio of $0.6-0.8$ and $0.7-0.9$, respectively, depending on the genotype analysed) [58]. Data on the efficacy of HPV vaccination for prevention of lesions are not available. No specific data on the safety of HPV vaccines in the MSM population were described in most of the studies evaluated.

Summary of previous guidelines or consensus recommendations

The Advisory Committee on Immunisation Practices (ACIP) recommends routine HPV vaccination for MSM aged 9-26 years, including transgender persons [20].

Recommendations in men who have sex with men HPV vaccination is recommended in MSM aged 9-26 years (quality of evidence: moderate; recommendation: strong). MSM aged 26 years and older may also benefit from HPV vaccination (quality of evidence: very low; recommendation: weak). The use of any of the available vaccines is indicated, although the quadrivalent or nonavalent vaccines are preferred given the high prevalence of anogenital warts in MSM. 
Inflammatory bowel disease

Treatment of inflammatory bowel disease IBD (Crohn's disease and ulcerative colitis) often includes immunosuppressants, which increase the risk of HPV persistence. Compared with patients not receiving immunosuppressive treatment, patients with IBD receiving azathioprine show a higher incidence of cutaneous warts and skin and genital herpes flares [59]. Although some studies have reported the development or worsening of genital condyloma in patients with IBD treated with anti-tumour necrosis factor (TNF) antibodies such as infliximab and etanercept [60,61], other studies suggest no relationship between the use of TNF antibodies and persistent HPV infection [62].

Controversy remains regarding to the increased risk of HPV infection and UCC in patients with IBD Vs the general population. A study of 40 patients with IBD showed a higher incidence of abnormal cervical cytology in women with IBD compared with similar healthy controls ( $42 \%$ vs $7 \% ; p<0.001$ ), and a higher incidence of lesions [63]. In this study, the use of immunosuppressants for at least 6 months was also associated to an increased risk of abnormal cytology (Odds ratio (OR): $1.5 ; 95 \%$ confidence interval $(\mathrm{Cl}): 1.2-4.1$; $\mathrm{p}$ value $=0.021$ ) [63]. A study of 116 women with IBD showed an increased rate of abnormal cervical cytology [64], while a population-based study of patients with Crohn's disease demonstrated an increased risk of UCC and dysplasia [65]. Another study showed an increased risk of both low-grade squamous intraepithelial lesions (LSIL), HSIL and UCC in patients with IBD vs a control group (incidence rate ratio for UCC in Crohn's disease: 1.53; 95\% Cl: 1.04-2.27) [66]. Case-control studies have not shown an increased risk of histological or cytological cervical abnormalities in women with IBD $[67,68]$.

\section{Rationale for recommendations}

One paper of HPV vaccination in IBD population was selected (Supplementary material Table S3). One study investigating the profile of the $\mathrm{GHPV}$ vaccine in patients with IBD showed an adequate immunogenicity and safety profile [69]. Similar antibody titres were induced in patients with IBD and healthy controls, although $49 \%$ of the IBD patients were receiving immunosuppressants and $51 \%$ were receiving anti-TNF antibodies. Some major adverse events were detected (exacerbations of IBD $(n=2)$, pneumonia $(n=1)$, ovarian torsion $(n=1)$, acute sinus pain $(n=1))$, but none of them appeared to be related to HPV vaccination.

Summary of previous guidelines or consensus recommendations

All guidelines regarding prevention of opportunistic infections in patients with IBD recommend regular clinical screening and HPV vaccination, particularly in patients receiving immunosuppressants [70-73].
Recommendations in inflammatory bowel disease patients

HPV vaccination is recommended for women with IBD aged 9-26 years (quality of evidence: low; recommendation: weak). Although vaccination can be administered at any time, it is preferable to vaccinate at the time of diagnosis and before the use of immunosuppressive or biological therapies, to ensure higher immunogenicity. There are no data supporting HPV vaccination in men with IBD.

\section{Women with HPV infection and precancerous cervical lesions}

In Spain, a large-scale study estimate that the prevalence of HPV infection is $13.4 \%$ and $7.9 \%$ in women aged $26-45$ and 46-65 years, respectively, compared with $28.8 \%$ in women aged $18-25$ years [74]. Rates of precancerous cervical lesions are reported between 0.4 and $0.7 \%$; the estimated number of women aged 18 years or older with HSIL (CIN) in Spain is in the range of 54,087-92,423 [75].

\section{Rationale for recommendations}

A substantial proportion of adult women become infected with HPV, particularly genotypes 16 and 18 . The probability of persistence increases with age, which consequently increases the risk of precancerous lesions or UCC developing. Women with precancerous cervical lesions have a $5-25 \%$ risk of recurrence and an increased risk of developing UCC compared with the general population [76]. This increased risk is mainly due to persistent HPV. Moreover, while in general the HPV infection clears after treatment, natural immunity does not provide complete protection against reactivation or reinfection by the same HPV genotype [75].

Three papers of HPV vaccination in women with HPV infection and precancerous cervical lesions were selected (Supplementary material Table S4). Precancerous lesions are generally diagnosed in women aged 25 years or older; data about HPV vaccination in this group of women are limited. However, a few studies focused on adult women and showed that both qHPV vaccine and the bivalent HPV vaccine are immunogenic, effective and safe in this age group [77,78]. Immunisation with the qHPV vaccine resulted in $64.9 \%$ (95\% Cl: 20.1-86.3) efficacy in preventing new cervical lesions by any HPV genotype in treated women [79]. Another study of 737 women undergoing cervical conisation showed that the qHPV vaccine was associated with a $65 \%$ reduction in HPV recurrence at 2 years, regardless of genotype $(2.5 \%$ vs $7.2 \%$ recurrences in vaccinated and unvaccinated women, respectively) [80]. The post-treatment risk reduction of new lesions following bivalent vaccine immunisation in women with surgically treated cervical lesions was $88.2 \%(95 \% \mathrm{Cl}$ : 14.8-99.7), regardless of genotype [81]. These studies demonstrate that HPV vaccination in women with cervical lesions who undergo treatment results in a significant reduction in the risk of new lesions. No specific 
safety data on the HPV vaccines in these populations was identified in any of the studies evaluated.

Summary of previous guidelines or consensus recommendations

In Spain, a consensus guideline from several scientific societies recommends HPV vaccination in sexually active women. Because of the increased risk of HPV infection and increased persistence of infection with age in women with prior HPV infection and viral clearance, the intention of this recommendation is to protect against reinfection and to reduce the risk of developing new lesions and UCC in women receiving treatment for cervical lesions [75].

Recommendations in women with HPV infection and precancerous cervical lesions

HPV vaccination is recommended in women undergoing treatment for precancerous cervical lesions (quality of evidence: moderate; recommendation: strong). Patients with precancerous cervical lesions who have not yet been treated, may benefit from HPV vaccination (quality of evidence: low; recommendation: strong). Ideally, the vaccine should be administered early, either at diagnosis or before cervical conisation.

Congenital bone marrow failure syndrome, primary immunodeficiency or survivors of childhood neoplasia

Congenital bone marrow failure syndrome (CBMFS) is a group of heterogeneous diseases associated with inadequate blood cell production, constitutional malformations and predisposition to cancer. Patients with Fanconi's anaemia and dyskeratosis congenita, both congenital bone marrow failure syndromes, are at risk of gynaecological and head and neck squamous cell carcinomas [82]. The increased risk of cancer in these patients means that cancer prevention strategies are essential.

Certain primary immunodeficiency conditions, such as epidermodysplasia verruciformis, hyper-IgE syndrome, idiopathic CD4 lymphopaenia, GATA2 deficiency and Warts-hypogammaglobulinaemia, infections and myelokathesis (WHIM) or Netherton's syndrome, have the presence of cutaneous warts as one of the main clinical manifestations of the disease [83]. Patients with these conditions are more susceptible to persistent HPV infection because of an impaired immune response to the virus, an increased risk of extensive skin involvement and a higher risk of precancerous cervical lesions progressing to malignancy.

Survivors of childhood, adolescent or young adulthood cancer e.g. Hematopoietic stem cell transplantation (HSCT) recipients, post-transplant survivors with chronic graft-vs-host disease receiving immunosuppressive therapy, individuals with a history of pelvic radiation and those with Hodgkin's lymphoma, are also at risk of adverse outcomes associated with HPV infection [84]. In one US study, male and female long-term cancer survivors had $150 \%$ and $40 \%$ more HPV-related malignancies, respectively, than the general population [85].

\section{Rationale for recommendations}

Two papers of HPV vaccination in CBMFS, primary immunodeficiency or survivors of childhood neoplasia were selected (Supplementary material Table S5). Patients with Fanconi's anaemia and dyskeratosys congenita have a similar immune response to HPV vaccination to that of the general population [86].

While live-attenuated vaccines are not feasible in patients with primary immunodeficiency, inactivated or subunit vaccines are considered safe [87] and could play an important role in the prevention of both malignancy and warts. Immunisation of a WHIM patient with the qHPV vaccine induced neutralising antibodies and a cellular immune response, indicating that patients with WHIM syndrome may benefit from HPV vaccination [88]. No safety data were reported in any of the studies analysed. Although most survivors of childhood neoplasia recover their immunity within 6 months of the end of chemotherapy or immunosuppressive therapy, the immunogenicity to HPV vaccines in this population is not well known so additional studies are needed.

Summary of previous guidelines or consensus recommendations

ACIP recommends routine HPV vaccination to primary immunodeficiency patients aged 9-26 years [20]. The Children's Oncology Group recommends HPV vaccination for all female survivors of childhood cancer $[89,90]$.

Recommendations in patients with congenital bone marrow failure syndrome, primary immunodeficiency or survivors of childhood neoplasia

HPV vaccination of patients with CBMFS is recommended (quality of evidence: low; recommendation: strong).

HPV vaccination may benefit patients with primary immunodeficiency (quality of evidence: very low; recommendation: weak). The use of any of the available vaccines is indicated, although the quadrivalent or nonavalent vaccines are preferred given the high prevalence of anogenital warts in these patients.

Survivors of childhood neoplasia can benefit from HPV vaccination (quality of evidence: very low; recommendation: weak).

\section{Solid organ or haematopoietic stem cell transplantation}

Patients who have undergone solid organ transplantation need life-long immunosuppressive therapy, which increases their risk of complications associated with persistent HPV infection. Studies have shown that immunosuppressed transplant recipients have an increased presence of HPV in the oral cavity, higher 
prevalence of genital warts [91], high oncogenic HPV in squamous cell skin cancer [92], an increased risk of anal cancer [93-95] and UCC [96-98].

Patients who have undergone HSCT have an increased risk of developing solid organ cancer [99]. In some studies, this risk was double that of the general population $[100,101]$. The increase in survival after HSCT has been associated with an increased prevalence of HSIL in these women $[102,103]$.

\section{Rationale for recommendations}

Three papers of HPV vaccination in solid organ or haematopoietic stem cell transplantation were selected [104-106] (Supplementary material Table S6). Epidemiological data show a high risk of gynaecological and other cancers in transplant recipients [102]. Limited data are available on the immunogenicity and efficacy of HPV vaccination in individuals who have undergone solid organ transplantation, and no information exists for HSCT recipients.

Summary of previous guidelines or consensus recommendations

ACIP recommends routine HPV vaccination for those aged 9-26 years for transplant patients [20].

The 2013 Infectious Diseases Society of America (IDSA) clinical practice guideline for vaccination of the immunocompromised host recommends that physicians consider the administration of three doses of HPV vaccine 6-12 months after HSCT for female patients aged 11-26 years and qHPV vaccine for males aged 11-26 years. The HPV vaccine series should also be administered to solid organ transplant candidates aged 11-26 years [27].

Recommendations in solid organ or haematopoietic stem cell transplant recipients

HPV vaccination is recommended in female transplant recipients aged 9-26 years (quality of evidence: low; recommendation: strong). Female patients aged 26 years and older may also benefit from HPV vaccination, particularly those with chronic graft vs host disease following HSCT (quality of evidence: very low; recommendation: weak). If possible, vaccination should be provided before solid organ transplantation and preferably before the use of immunosuppressive or biological therapies to ensure high immunogenicity. Vaccination is not recommended within 6 months post-transplantation. Patients undergoing HSCT should be vaccinated 6-12 months after transplantation, even if vaccinated beforehand.

\section{Immunosuppressive or biological treatment} Immunosuppression is an important risk factor for cervical HPV infection [107]. HPV has a predilection for epithelial cells and causes an abnormal proliferation of keratinocytes, which may manifest as benign warts or malignant neoplasms. The host immune response to HPV infection is initiated by cytokines and chemokines that are secreted by the virally stimulated keratinocyte. If the immune response is sufficient HPV lesions may regress, but this resolution of HPV lesions is not generally seen in the immunosuppressed patients resulting in severe, persistent and extensive manifestations of HPV disease [108]. Among patients undergoing therapeutic immunosuppression, evidence is restricted to some disease types e.g. systemic lupus erythematosus (SLE) or juvenile idiopathic arthritis (JIA) and rarely stratified by therapeutic modality or dosage.

Some studies have shown an increase in the prevalence of HPV infection, dysplasia and premalignant lesions in patients with SLE and those with kidney failure undergoing haemodialysis [107,109]. A systematic review of studies in patients with SLE concluded that they are at higher risk of cervical dysplasia and precancerous lesions. However, most studies show a similar prevalence of UCC in patients with SLE compared with the general population [110]. A delay in HPV clearance and a greater persistence of infection and HPV-associated lesions in SLE patients could be explained by alterations in the innate and adaptive immune response in this population [111]. However, the role of immunosuppressants as a predisposing factor to HPV-associated cervical lesions is unconfirmed $[102,112]$.

TNF blockers are widely used to treat chronic inflammatory diseases. TNF plays an essential part in host defence and the immune response. Although uncommon, cases of extensive cutaneous HPV lesions have been reported following TNF blocking therapy $[61,113,114]$.

Rationale for recommendations

The high rates of HPV infection and associated lesions in immunocompromised individuals justify the need to consider vaccination in this population [107]. Although published data are limited to some groups of patients, evidence suggests that women with SLE are at an increased risk of developing HPV-related lesions. As SLE is an immune disorder that predominantly affects women, most subjects in studies evaluating the risk of HPV infection and lesions in SLE patients are women [110].

Five papers of HPV vaccination in patients with immunosuppressive or biological treatment were selected. (Supplementary material Table S7) [115-119]. In the largest study, administration of the qHPV vaccine resulted in similar seroconversion rates to the general population 12 months post-vaccination [115]. Lower seroconversion rates were seen in patients receiving treatment with prednisolone or mycophenolate mofetil. There were no safety issues or an increased risk of SLE flares seen with vaccination [115].

Two studies evaluating the immunogenicity and safety of HPV vaccines in JIA patients have been published $[118,119]$. One was a prospective cohort study including 68 females aged $12-18$ years with JIA who were 
TABLE

Summary of recommendations regarding human papillomavirus vaccination in high-risk populations

\begin{tabular}{|c|c|c|c|}
\hline High-risk population & Summary and recommendations & $\begin{array}{l}\text { Quality of } \\
\text { evidence }\end{array}$ & $\begin{array}{l}\text { Recommendation } \\
\text { strength }\end{array}$ \\
\hline \multirow{2}{*}{ HIV infection } & $\begin{array}{l}\text { HPV vaccination is recommended in HIV patients through age } \\
26 \text {, regardless of gender }\end{array}$ & Moderate & Strong \\
\hline & $\begin{array}{l}\text { HIV-positive patients aged } \geq 26 \text { years may also benefit from } \\
\text { HPV vaccination }\end{array}$ & Low & Weak \\
\hline \multirow{2}{*}{ MSM } & HPV vaccination in MSM through age 26 is recommended & Moderate & Strong \\
\hline & MSM aged $\geq 26$ years may benefit from HPV vaccination & Very Low & Weak \\
\hline IBD & $\begin{array}{l}\text { HPV vaccination is recommended in women with IBD through } \\
\text { age } 26\end{array}$ & Low & Weak \\
\hline \multirow{2}{*}{$\begin{array}{l}\text { Women with premalignant } \\
\text { cervical lesions }\end{array}$} & $\begin{array}{l}\text { HPV vaccination is recommended in women treated for } \\
\text { precancerous cervical lesions }\end{array}$ & Moderate & Strong \\
\hline & $\begin{array}{c}\text { Women with untreatable intraepithelial lesions may benefit } \\
\text { from HPV vaccination }\end{array}$ & Low & Strong \\
\hline CBMFS & HPV vaccination is recommended in patients with CBMFS & Low & Strong \\
\hline Primary immunodeficiency & $\begin{array}{l}\text { Patients with primary immunodeficiency may benefit from HPV } \\
\text { vaccination }\end{array}$ & Very low & Weak \\
\hline Survivors of childhood neoplasia & $\begin{array}{l}\text { Survivors of childhood cancer may benefit from HPV } \\
\text { vaccination }\end{array}$ & Very low & Weak \\
\hline \multirow[b]{2}{*}{$\begin{array}{l}\text { Solid organ transplantation or } \\
\text { HSCT }\end{array}$} & $\begin{array}{l}\text { HPV vaccination is recommended in women through age } 26 \\
\text { who have received a solid organ transplant or HSCT }\end{array}$ & Low & Strong \\
\hline & $\begin{array}{c}\text { Female patients aged } \geq 26 \text { years may benefit from HPV } \\
\text { vaccination, particularly those with chronic graft-vs-host } \\
\text { disease after HSCT }\end{array}$ & Very low & Weak \\
\hline $\begin{array}{l}\text { Immunosuppressive or biological } \\
\text { treatment }\end{array}$ & $\begin{array}{c}\text { HPV vaccination is recommended in women receiving } \\
\text { immunosuppressive and/or biological treatment through age } \\
26 \text { (in particular women with SLE or JIA) }\end{array}$ & Low & Weak \\
\hline RRP & $\begin{array}{l}\text { HPV vaccination is recommended in patients diagnosed with } \\
\text { RRP through age } 26\end{array}$ & Low & Strong \\
\hline
\end{tabular}

CBMFS: congenital bone marrow failure syndrome; HIV: human immunodeficiency virus; HPV: human papillomavirus; HSCT: haematological stem cell transplantation; IBD: inflammatory bowel disease; JIA: juvenile idiopathic arthritis; MSM: men who have sex with men; RRP: recurrent respiratory papillomatosis; SLE: systemic lupus erythematosus.

vaccinated with bivalent HPV vaccine. The vaccine showed a strong HPV 16/18-specific antibody response that was comparable with the response seen in healthy female adolescents; HPV-specific geometric mean concentrations (GMCs) were consistently lower in JIA patients. No effect of methotrexate or anti-TNF treatment on the vaccine response was observed and no safety concerns were found [118]. Another prospective cohort study including 21 female patients with JIA aged 12-25 years and 21 healthy controls immunised with bivalent HPV vaccine showed significantly lower HPV 16 neutralising antibody titres in JIA patients than controls, but no significant difference in HPV-18 antibody titres. Immunoresponse to the vaccine did not seem to be affected by the type of anti-rheumatic therapy the patients were receiving. The vaccine was safe and well tolerated [119].

At present, there are no published data from randomised clinical trials on the efficacy, immunogenicity or safety of HPV vaccination in patients receiving immunosuppressive and/or biological treatment.
Summary of previous guidelines or consensus recommendations

The evidence-based recommendations on vaccination in patients with autoimmune rheumatic diseases from the European League against Rheumatism specify that HPV vaccination should be considered in women with SLE aged less than 26 years [120].

ACIP recommends routine HPV vaccination for immunosuppressed patients aged $9-26$ years [20].

The 2013 IDSA clinical practice guideline for vaccination of the immunocompromised host recommends HPV vaccination for females and males 11-26 years old with chronic inflammatory diseases on immunosuppressive medications [27].

Recommendations in patients receiving immunosuppressive or biological treatment HPV vaccination is recommended in women receiving immunosuppressive and/or biological treatment aged 9-26 years, in particular, women with SLE or JIA (quality of evidence: low; recommendation: weak). While the vaccine can be given at any time, administration before 
the use of immunosuppressive or biological therapies is preferable. There are no data supporting HPV vaccination in males receiving immunosuppressive or biological therapy.

\section{Recurrent respiratory papillomatosis}

Recurrent respiratory papillomatosis (RRP) is characterised by the presence of multiple papilloma in the airway that cause obstructive symptoms such as shortness of breath, hoarseness or stridor [121]. The disease may occur in children (aged $\leq 17$ years) or adults $[9,122]$. The incidence of both juvenile and adult forms of RRP is estimated at 3-7 per 100,000 individuals [123,124]. HPV infection is the cause of RRP, with genotypes 6 and 11 present in $90-95 \%$ of cases [9].

\section{Rationale for recommendations}

Nine papers of HPV vaccination in patients with recurrent respiratory papillomatosis were selected (Supplementary material Table S8). No randomised clinical trials on the efficacy of HPV vaccine have been conducted in individuals with RRP. Several studies have investigated the effectiveness of the quadrivalent vaccine in both juvenile RRP [122,125-131] and adult RRP $[122,126,130,132]$ Supplementary material Table S8). Vaccination-induced partial or complete remission in a substantial proportion of the RRP patients, and no remarkable adverse effects were reported.

Summary of previous guidelines or consensus recommendations

There are no guideline or consensus documents that specifically recommend HPV vaccination in patients with RRP.

\section{Recommendations in patients with RRP}

HPV vaccination is recommended in patients with RRP aged 9-26 years (quality of evidence: low; recommendation: strong). Given the relationship of RRP to HPV genotypes 6 and 11, the use of the quadrivalent or nonavalent vaccine is recommended. Despite scarce data, the potential benefit should outweigh the risk of vaccination; therefore compassionate use may be considered in juvenile patients who are under the age indicated in the summary of product characteristics for the vaccine.

\section{Summary of recommendations}

Data concerning non-routine HPV vaccination in populations with a high risk of HPV infection and associated lesions are scarce, and recommendations differ between countries. The evidence-based recommendations for HPV vaccination in high-risk populations conducted by an independent expert panel are summarised in Table.

\section{Conclusions}

Systematic HPV vaccination is considered the most effective intervention for controlling the infection and preventing HPV-related disease burden. Along with other interventions, such as information, screening and treatment, HPV vaccination is crucial in the prevention of uterine cervical cancer.

In all high-risk populations, based on the summary and recommendations, the quality of evidence was found to be very low to moderate. A strong recommendation about HPV vaccination was made in HIV infected patients aged 9-26 years; men who have sex with men aged 9-26 years; women with precancerous cervical lesions; patients with congenital bone marrow failure syndrome; women who have received a solid organ transplant or hematopoietic stem cell transplantation aged 9-26 years; and patients diagnosed with recurrent respiratory papillomatosis. In the rest of high-risk categories with only a weak recommendation (HIVpositive patients aged $\geq 26$ years, MSM aged $\geq 26$, IBD, patients with primary immunodeficiency, survivors of childhood neoplasia, women who have received a solid organ transplant or hematopoietic stem cell transplantation aged $\geq 26$ years and patients in immunosuppressive or biological treatment), the quality of evidence was low or very low. Further studies are needed.

\section{Note}

Author Xavier Castellsagué passed away 12 June 2016.

\section{Acknowledgements}

We would like to thank Sheridan Henness, PhD, and Sarah Greig, PhD, of Springer Healthcare Communications who wrote the outline and first draft of this manuscript. This medical writing assistance was funded by the Spanish Association of Cervical Pathology and Colposcopy (AEPCC).

The guideline on HPV vaccination in high-risk individuals was reviewed and endorsed by the Spanish Association of Cervical Pathology and Colposcopy (Asociación Española de Patología Cervical y Colposcopia (AEPCC)), the Spanish Association of Paediatrics (Asociación Española de Pediatría (AEP)), the Spanish Association of Vaccinology (Asociación Española de Vacunología (AEV)), the Spanish Society of Paediatric Haematology and Oncology (Sociedad Española de Hematología y Oncología Pediátricas (SEHOP)), the Spanish Society of Haematology and Haemostasis (Sociedad Española de Hematología y Hemoterapia (SEHH)), the Spanish Society of Primary Care Doctors (Sociedad Española de Médicos de Atención Primaria (SEMERGEN)), the Spanish Society of Community and Family Medicine (Sociedad Española de Medicina de Familia y Comunitaria (semFYC)), the Spanish Society of Preventive Medicine, Public Health and Hygiene (Sociedad Española de Medicina Preventiva, Salud Pública e Higiene (SEMPSPH)), the Study Group of Sexually Transmitted Diseases of the Spanish Society of Infectious Diseases and Clinical Microbiology (Grupo de Estudio de las Infecciones de Transmisión Sexual (GeITS) de la Sociedad Española de Enfermedades Infecciosas y Microbiología Clínica (SEIMC)) and the Spanish Working Group in Crohn's Disease and Ulcerative Colitis (Grupo Español de Trabajo en Enfermedad de Crohn y Colitis Ulcerosa (GETECCU)).

\section{Conflict of interest}

Several authors have received economical funds for research through their working institutions from Sanofi Pasteur MSD 
and MSD and received speakers' fees from GSK and/or Sanofi Pasteur MSD and MSD.

\section{Authors' contributions}

All authors have contributed to bibliographic search, critical review of papers, GRADE classification of recommendations and manuscript writing. Xavier Martínez and José Ángel Rodrigo Pendás designed and carried out the electronic bibliographic search, selected the references for full-text reading after the screening of the title and abstract of all the studies retrieved and selected the papers finally included. Xavier Martínez and Magda Campins have also drafted the first version of the manuscript and have incorporated all the modifications recommended by the other authors.

\section{References}

1. Bosch FX, Lorincz A, Muñoz N, Meijer CJ, Shah KV. The causal relation between human papillomavirus and cervical cancer. J Clin Pathol. 2002;55(4):244-65. https://doi.org/10.1136/ jcp.55.4.244 PMID: 11919208

2. Walboomers JM, Jacobs MV, Manos MM, Bosch FX, Kummer JA, Shah KV, et al. Human papillomavirus is a necessary cause of invasive cervical cancer worldwide. J Pathol. 1999;189(1):12-9. https://doi.org/10.1002/(SICI)10969896(199909)189:1<12::AID-PATH431/3.0.CO;2-F PMID: 10451482

3. Alemany L, Saunier M, Tinoco L, Quirós B, AlvaradoCabrero I, Alejo M, et al. HPV VVAP study group. Large contribution of human papillomavirus in vaginal neoplastic lesions: a worldwide study in 597 samples. Eur J Cancer. 2014;50(16):2846-54. https://doi.org/10.1016/j. ejca.2014.07.018 PMID: 25155250

4. de Sanjosé S, Alemany L, Ordi J, Tous S, Alejo M, Bigby SM, et al. HPV VVAP study group. Worldwide human papillomavirus genotype attribution in over 2000 cases of intraepithelial and invasive lesions of the vulva. Eur J Cancer. 2013;49(16):345061. https://doi.org/10.1016/j.ejca.2013.06.033 PMID: 23886586

5. Alemany L, Cubilla A, Halec G, Kasamatsu E, Quirós $B$, Masferrer E, et al. HPV VVAP study group. Role of Human Papillomavirus in Penile Carcinomas Worldwide. Eur Urol. 2016;69(5):953-61. https://doi.org/10.1016/j. eururo.2015.12.007 PMID: 26762611

6. Alemany L, Saunier M, Alvarado-Cabrero I, Quirós B, Salmeron J, Shin HR, et al. HPV VVAP Study Group. Human papillomavirus DNA prevalence and type distribution in anal carcinomas worldwide. Int J Cancer. 2015;136(1):98-107. https://doi. org/10.1002/ijc.28963 PMID: 24817381

7. Castellsagué X, Alemany L, Quer M, Halec G, Quirós B, Tous $S$, et al. ICO International HPV in Head and Neck Cancer Study Group. HPV Involvement in Head and Neck Cancers: Comprehensive Assessment of Biomarkers in 3680 Patients. J Natl Cancer Inst. 2016;108(6):djv403. https://doi.org/10.1093/ jnci/djv403 PMID: 26823521

8. Garland SM, Steben M, Sings HL, James M, Lu S, Railkar R, et al. Natural history of genital warts: analysis of the placebo arm of 2 randomized phase III trials of a quadrivalent human papillomavirus (types $6,11,16$, and 18 ) vaccine. J Infect Dis. 2009;199(6):805-14. https://doi.org/10.1086/597071 PMID: 19199546

9. Gillison ML, Alemany L, Snijders PJ, Chaturvedi A, Steinberg BM, Schwartz S, et al. Human papillomavirus and diseases of the upper airway: head and neck cancer and respiratory papillomatosis. Vaccine. 2012;30(Suppl 5):F34-54. https://doi. org/10.1016/j.vaccine.2012.05.070 PMID: 23199965

10. Castellsagué $X$. Natural history and epidemiology of HPV infection and cervical cancer. Gynecol Oncol. 2008;110(3) Suppl 2;S4-7. https://doi.org/10.1016/j.ygyno.2008.07.045 PMID: 18760711

11. Giuliano AR, Anic G, Nyitray AG. Epidemiology and pathology of HPV disease in males. Gynecol Oncol. 2010;117(2) Suppl;S15-9. https://doi.org/10.1016/j.ygyno.2010.01.026 PMID: 20138345

12. de Martel C, Plummer M, Vignat J, Franceschi S. Worldwide burden of cancer attributable to HPV by site, country and HPV type. Int J Cancer. 2017;141(4):664-70. https://doi. org/10.1002/ijc.30716 PMID: 28369882

13. Serrano B, Brotons M, Bosch FX, Bruni L. Epidemiology and burden of HPV-related disease. Best Pract Res Clin
Obstet Gynaecol. 2018;47:14-26. https://doi.org/10.1016/j. bpobgyn.2017.08.006 PMID: 29037457

14. World Health Organization (WHO). Human papillomavirus vaccines: WHO position paper, May 2017. Wkly Epidemiol Rec. 2017;92(19):241-68. PMID: 28530369

15. GlaxoSmithKline. Cervarix suspension for injection: summary of product characteristics: GlaxoSmithKline; 2012. Available from: http://www.ema.europa.eu/docs/en_GB/document_ library/EPAR_-_Product_Information/human/000721/ WC $500024632 . p d f$

16. Merck Sharp \& Dohme BV. Gardasil suspension for injection: summary of product characteristics. Stockholm: Merck Sharp \& Dohme BV;2011. Available from: http://www.ema.europa.eu/ docs/en_GB/document_library/EPAR_-_Product_Information/ human/000703/WC500021142.pdf

17. Merck Sharp \& Dohme BV. Gardasil 9 suspension for injection: summary of product characteristics. Merck Sharp \& Dohme BV; 2015. Available from: http://www.ema.europa.eu/docs/ en_GB/document_library/EPAR_-_Product_Information/ human/o03852/WC500189111.pdf

18. European Centre for Disease Prevention and Control (ECDC). Vaccine schedules in all countries of the European Union. Stockholm: ECDC. Available from: http://vaccine-schedule. ecdc.europa.eu/Pages/Scheduler.aspx [Accessed 3 Jul 2018].

19. Markowitz LE, Dunne EF, Saraiya M, Chesson HW, Curtis CR, Gee J, et al. Centers for Disease Control and Prevention (CDC). Human papillomavirus vaccination: recommendations of the Advisory Committee on Immunization Practices (ACIP). MMWR Recomm Rep. 2014;63(RR-05):1-30. PMID: 25167164

20. Kim DK, Riley LE, Harriman KH, Hunter P, Bridges CBAdvisory Committee on Immunization Practices. Recommended Immunization Schedule for Adults Aged 19 Years or Older, United States, 2017. Ann Intern Med. 2017;166(3):209-19. https://doi.org/10.7326/M16-2936 PMID: 28166560

21. Australian Technical Advisory Group on Immunisation (ATAGI). The Australian immunisation handbook 1oth ed (2015 update) Canberra: Australian Government Department of Health; 2015

22. National Advisory Committee on Immunization (NACl). Update on the recommended Human Papillomavirus (HPV) vaccine immunization schedule. Ottawa: $\mathrm{NACl} ; 2015$. Available from: http://www.phac-aspc.gc.ca/naci-ccni/acs-dcc/2015/hpvvph_0215-eng.php

23. Public Health England (PHE). Human papillomavirus (HPV) vaccination for Men who have sex with Men (MSM) 2016/17 pilot evaluation. London: PHE; 2016. Available from: https:// assets.publishing.service.gov.uk/government/uploads/ system/uploads/attachment_data/file/678987/HPV_msm year1_evaluation_report.pd

24. Asociación Española de Patología Cervicaly Colposcopia (AEPCC). Vacunación selectiva frente al virus del papiloma humano en poblaciones de riesgo elevado. [Selective vaccination against human papillomavirus in high-risk populations].AEPCC; 2016. Spanish. Available from: http:// www.aepcc.org/wp-content/uploads/2016/12/AEPCC revista07_VACUNACION-SELECTIVA.pdf

25. Landis JR, Koch GG. The measurement of observer agreement for categorical data. Biometrics. 1977;33(1):159-74. https://doi. org/10.2307/2529310 PMID: 843571

26. Andrews J, Guyatt G, Oxman AD, Alderson P, Dahm P, FalckYtter Y, et al. GRADE guidelines: 14. Going from evidence to recommendations: the significance and presentation of recommendations. J Clin Epidemiol. 2013;66(7):719-25. PMID: 23312392

27. Rubin LG, Levin MJ, Ljungman P, Davies EG, Avery R, Tomblyn $M$, et al. 2013 IDSA clinical practice guideline for vaccination of the immunocompromised host. Clin Infect Dis. 2014;58(3):e44100. https://doi.org/10.1093/cid/cit684 PMID: 24311479

28. Darwich L, Cañadas MP, Videla S, Coll J, Molina-López RA, Sirera G, et al. Can Ruti HIV-HPV Team. Prevalence, clearance, and incidence of human papillomavirus type-specific infection at the anal and penile site of HIV-infected men. Sex Transm Dis. 2013;40(8):611-8. https://doi.org/10.1097/01. OLQ.0000430798.61475.08 PMID: 23859907

29. de Pokomandy A, Rouleau D, Ghattas G, Vézina S, Coté P, Macleod J, et al. HIPVIRG Study Group. Prevalence, clearance, and incidence of anal human papillomavirus infection in HIV-infected men: the HIPVIRG cohort study. J Infect Dis. 2009;199(7):965-73. https://doi.org/10.1086/597207 PMID: 19239366

30. Geskus RB, González C, Torres M, Del Romero J, Viciana $\mathrm{P}$, Masiá M, et al. CoRIS-HPV Study Group. Incidence and clearance of anal high-risk human papillomavirus in HIVpositive men who have sex with men: estimates and risk factors. AIDS. 2016;30(1):37-44. PMID: 26355673

31. Silverberg MJ, Lau B, Justice AC, Engels E, Gill MJ, Goedert JJ, et al. North American AIDS Cohort Collaboration on Research 
and Design (NA-ACCORD) of leDEA. Risk of anal cancer in HIVinfected and HIV-uninfected individuals in North America. Clin Infect Dis. 2012;54(7):1026-34. https://doi.org/10.1093/cid/ cir1012 PMID: 22291097

32. Conley LJ, Ellerbrock TV, Bush TJ, Chiasson MA, Sawo D, Wright TC. HIV-1 infection and risk of vulvovaginal and perianal condylomata acuminata and intraepithelial neoplasia: a prospective cohort study. Lancet. 2002;359(9301):108-13. https://doi.org/10.1016/S0140-6736(02)07368-3 PMID: 11809252

33. Massad LS, Silverberg MJ, Springer G, Minkoff H, Hessol N, Palefsky JM, et al. Effect of antiretroviral therapy on the incidence of genital warts and vulvar neoplasia among women with the human immunodeficiency virus. Am J Obstet Gynecol. 2004;190(5):1241-8. https://doi.org/10.1016/j. ajog.2003.12.037 PMID: 15167825

34. Darwich L, Cañadas MP, Videla S, Coll J, Piñol M, Cobarsi P, et al. HIV-HPV Can Ruti Team. Condylomata, cytological abnormalities and human papillomavirus infection in the anal canal in HIV-infected men. HIV Med. 2012;13(9):54957. https://doi.org/10.1111/j.1468-1293.2012.01013.x PMID: 22435501

35. Levin MJ, Moscicki AB, Song LY, Fenton T, Meyer WA 3rd, Read JS, et al. IMPAACT P1047 Protocol Team. Safety and immunogenicity of a quadrivalent human papillomavirus (types $6,11,16$, and 18 ) vaccine in HIV-infected children 7 to 12 years old. J Acquir Immune Defic Syndr. 2010;55(2):197-204. https:// doi.org/10.1097/QAl.ob013e3181de8d26 PMID: 20574412

36. Kahn JA, Xu J, Kapogiannis BG, Rudy B, Gonin R, Liu N, et al. Immunogenicity and safety of the human papillomavirus 6, 11, 16,18 vaccine in HIV-infected young women. Clin Infect Dis. 2013;57(5):735-44. https://doi.org/10.1093/cid/cit319 PMID: 23667266

37. Giacomet V, Penagini F, Trabattoni D, Viganò A, Rainone V, Bernazzani G, et al. Safety and immunogenicity of a quadrivalent human papillomavirus vaccine in HIVinfected and HIV-negative adolescents and young adults. Vaccine. 2014;32(43):5657-61. https://doi.org/10.1016/j. vaccine.2014.08.011 PMID: 25149430

38. Denny L, Hendricks B, Gordon C, Thomas F, Hezareh M, Dobbelaere K, et al. Safety and immunogenicity of the HPV$16 / 18$ ASo4-adjuvanted vaccine in HIV-positive women in South Africa: a partially-blind randomised placebo-controlled study. Vaccine. 2013;31(48):5745-53. https://doi.org/10.1016/j. vaccine.2013.09.032 PMID: 24091311

39. Kojic EM, Kang M, Cespedes MS, Umbleja T, Godfrey C, Allen RT, et al. Immunogenicity and safety of the quadrivalent human papillomavirus vaccine in HIV-1-infected women. Clin Infect Dis. 2014;59(1):127-35. https://doi.org/10.1093/cid/ciu238 PMID: 24723284

40. Wilkin T, Lee JY, Lensing SY, Stier EA, Goldstone SE, Berry JM, et al. Safety and immunogenicity of the quadrivalent human papillomavirus vaccine in HIV-1-infected men. J Infect Dis. 2010;202(8):1246-53. https://doi.org/10.1086/656320 PMID: 20812850

41. Toft L, Storgaard M, Müller M, Sehr P, Bonde J, Tolstrup M, et al. Comparison of the immunogenicity and reactogenicity of Cervarix and Gardasil human papillomavirus vaccines in HIV-infected adults: a randomized, double-blind clinical trial. J Infect Dis. 2014;209(8):1165-73. https://doi.org/10.1093/ infdis/jit657 PMID: 24273179

42. Money DM, Moses E, Blitz S, Vandriel SM, Lipsky N, Walmsley SL, et al. HPV in HIV Study Group. HIV viral suppression results in higher antibody responses in HIV-positive women vaccinated with the quadrivalent human papillomavirus vaccine. Vaccine. 2016;34(40):4799-806. https://doi.org/10.1016/j. vaccine.2016.08.016 PMID: 27544584

43. Fontes A, Andreoli MA, Villa LL, Assone T, Gaester K, Fonseca LAM, et al. High specific immune response to a bivalent anti-HPV vaccine in HIV-1-infected men in São Paulo, Brazil. Papillomavirus Res. 2016;2:17-20. https://doi.org/10.1016/j. pvr.2016.01.001 PMID: 29074177

44. Palefsky JM, Giuliano AR, Goldstone S, Moreira ED Jr, Aranda $C$, Jessen $H$, et al. HPV vaccine against anal HPV infection and anal intraepithelial neoplasia. N Engl J Med. 2011;365(17):157685. https://doi.org/10.1056/NEJMoa1010971 PMID: 22029979

45. Washington University School of Medicine. The effect of HPV vaccination on recurrence rates in HIV patients with condylomata. St Louis: Washington University School of Medicine; 2016. Available from: https://clinicaltrials.gov/ct2/ show/NCToo941889

46. University of the Witwatersrand. Randomized, double blind trial of the quadrivalent HPV vaccine to improve responses to LEEP treatment of cervical HSIL. Johannesburg: University of the Witwatersrand; 2017. Available from: https://clinicaltrials. gov/ct2/show/NCT01928225
47. Academisch Medisch Centrum - Universiteit van Amsterdam (AMC-UvA). HPV (human papilloma virus) vaccination after treatment of anal intraepithelial neoplasia (AIN) (VACCAIN-P). Amsterdam: AMC-UVA; 2018. Available from: https:// clinicaltrials.gov/ct2/show/NCT02087384

48. European AIDS Clinical Society (EACS). Clinical managemen and treatment of HIV infected adults in Europe, version 8.0. Brussels: EACS; 2015. Available from: http://www.eacsociety. org/files/2015_eacsguidelines_8_o-english_rev-20160124.pdf

49. Panel on Opportunistic Infections in HIV-Infected Adults and Adolescents. Guidelines for the prevention and treatment of opportunistic infections in HIV-infected adults and adolescents: recommendations from the Centers for Disease Control and Prevention, the National Institutes of Health, and the HIV Medicine Association of the Infectious Diseases Society of America. [Accessed 3 Jul 2018]. Available from: http://aidsinfo.nih.gov/contentfiles/lvguidelines/adult_oi.pdf.

50. D’Souza G, Wiley DJ, Li X, Chmiel JS, Margolick JB, Cranston $\mathrm{RD}$, et al. Incidence and epidemiology of anal cancer in the multicenter AIDS cohort study. J Acquir Immune Defic Syndr. 2008;48(4):491-9. https://doi.org/10.1097/ QAl.ob013e31817aebfe PMID: 18614927

51. Daling JR, Madeleine MM, Johnson LG, Schwartz SM, Shera KA, Wurscher MA, et al. Human papillomavirus, smoking, and sexual practices in the etiology of anal cancer. Cancer. 2004;101(2):270-80. https://doi.org/10.1002/cncr.20365 PMID: 15241823

52. Goldstone SE, Hundert JS, Huyett JW. Infrared coagulator ablation of high-grade anal squamous intraepithelial lesions in HIV-negative males who have sex with males. Dis Colon Rectum. 2007;50(5):565-75. https://doi.org/10.1007/s10350006-0874-x PMID: 17380365

53. Centers for Disease Control and Prevention (CDC). Sexually transmitted disease surveillance 2014. Atlanta: CDC;2015. Available from: http://www.cdc.gov/std/stats14/surv-2014print.pdf

54. Giuliano AR, Palefsky JM, Goldstone S, Moreira ED Jr, Penny $M E$, Aranda C, et al. Efficacy of quadrivalent HPV vaccine against HPV Infection and disease in males. N Engl J Med. 2011;364(5):401-11. https://doi.org/10.1056/NEJMoao909537 PMID: 21288094

55. Hillman RJ, Giuliano AR, Palefsky JM, Goldstone S, Moreira ED Jr, Vardas E, et al. Immunogenicity of the quadrivalent human papillomavirus (type 6/11/16/18) vaccine in males 16 to 26 years old. Clin Vaccine Immunol. 2012;19(2):261-7. https://doi. org/10.1128/CVI.05208-11 PMID: 22155768

56. Swedish KA, Goldstone SE. Prevention of anal condyloma with quadrivalent human papillomavirus vaccination of older men who have sex with men. PLoS One. 2014;9(4):e93393. https:// doi.org/10.1371/journal.pone.0093393 PMID: 24714693

57. Swedish KA, Factor SH, Goldstone SE. Prevention of recurrent high-grade anal neoplasia with quadrivalent human papillomavirus vaccination of men who have sex with men: a nonconcurrent cohort study. Clin Infect Dis. 2012;54(7):891-8. https://doi.org/10.1093/cid/cir1036 PMID: 22291111

58. Castellsagué X, Giuliano AR, Goldstone S, Guevara A, Mogensen O, Palefsky JM, et al. Immunogenicity and safety of the 9-valent HPV vaccine in men. Vaccine. 2015;33(48):6892901. https://doi.org/10.1016/j.vaccine.2015.06.088 PMID: 26144901

59. Seksik P, Cosnes I, Sokol H, Nion-Larmurier I, Gendre JP Beaugerie L. Incidence of benign upper respiratory tract infections, HSV and HPV cutaneous infections in inflammatory bowel disease patients treated with azathioprine. Aliment Pharmacol Ther. 2009;29(10):1106-13. https://doi.org/10.1111/ j.1365-2036.2009.03973.x PMID: 19222411

6o. Somasekar A, Alcolado R. Genital condylomata in a patient receiving infliximab for Crohn's disease. Postgrad Med J. 2004;80(944):358-9. https://doi.org/10.1136/ pgmj.2003.009332 PMID: 15192172

61. Antoniou C, Kosmadaki MG, Stratigos AJ, Katsambas AD. Genital HPV lesions and molluscum contagiosum occurring in patients receiving anti-TNF-alpha therapy. Dermatology. 2008;216(4):364-5. https://doi.org/10.1159/000117709 PMID: 18285688

62. Handisurya A, Lázár S, Papay P, Primas C, Haitel A, Horvat $\mathrm{R}$, et al. Anogenital Human Papillomavirus Prevalence is Unaffected by Therapeutic Tumour Necrosis Factor-alpha Inhibition. Acta Derm Venereol. 2016;96(4):494-8. https://doi. org/10.2340/00015555-2298 PMID: 26581127

63. Kane S, Khatibi B, Reddy D. Higher incidence of abnormal Pap smears in women with inflammatory bowel disease. Am J Gastroenterol. 2008;103(3):631-6. https://doi.org/10.1111/ j.1572-0241.2007.01582.x PMID: 17941962

64. Bhatia J, Bratcher J, Korelitz B, Vakher K, Mannor S, Shevchuk M, et al. Abnormalities of uterine cervix in women 
with inflammatory bowel disease. World J Gastroenterol. 2006;12(38):6167-71. https://doi.org/10.3748/wjg.v12.i38.6167 PMID: 17036389

65. Jess T, Horváth-Puhó E, Fallingborg J, Rasmussen $\mathrm{HH}$, Jacobsen BA. Cancer risk in inflammatory bowel disease according to patient phenotype and treatment: a Danish population-based cohort study. Am J Gastroenterol. 2013;108(12):1869-76. https://doi.org/10.1038/ajg.2013.249 PMID: 23978954

66. Rungoe C, Simonsen J, Riis L, Frisch M, Langholz E, Jess T. Inflammatory bowel disease and cervical neoplasia: a population-based nationwide cohort study. Clin Gastroenterol Hepatol. 2015;13(4):693-700.e1.

67. Singh H, Demers AA, Nugent Z, Mahmud SM, Kliewer EV, Bernstein CN. Risk of cervical abnormalities in women with inflammatory bowel disease: a population-based nested casecontrol study. Gastroenterology. 2009;136(2):451-8. https:// doi.org/10.1053/j.gastro.2008.10.021 PMID: 18996382

68. Lees CW, Critchley J, Chee N, Beez T, Gailer RE, Williams AR, et al. Lack of association between cervical dysplasia and IBD: a large case-control study. Inflamm Bowel Dis. 2009;15(11):16219. https://doi.org/10.1002/ibd.20959 PMID: 19618462

69. Jacobson DL, Bousvaros A, Ashworth L, Carey R, Shrier LA, Burchett SK, et al. Immunogenicity and tolerability to human papillomavirus-like particle vaccine in girls and young women with inflammatory bowel disease. Inflamm Bowel Dis. 2013;19(7):1441-9. https://doi.org/10.1097/ MIB.obo13e318281341b PMID: 23567780

70. Annese V, Beaugerie L, Egan L, Biancone L, Bolling C, Brandts C, et al. ECCO. European Evidence-based Consensus: Inflammatory Bowel Disease and Malignancies. J Crohn's Colitis. 2015;9(11):945-65. https://doi.org/10.1093/ecco-jcc/ jjv141 PMID: 26294789

71. Campins M, Cossio Y, Martínez X, Borruel N. Vaccination of patients with inflammatory bowel disease. Practical recommendations. Rev Esp Enferm Dig. 2013;105(2):93-102. https://doi.org/10.4321/S1130-01082013000200006 PMID: 23659508

72. Rahier JF, Magro F, Abreu C, Armuzzi A, Ben-Horin S, Chowers $Y$, et al. Second European evidence-based consensus on the prevention, diagnosis and management of opportunistic infections in inflammatory bowel disease. J Crohn's Colitis. 2014;8(6):443-68. https://doi.org/10.1016/j. crohns.2013.12.013 PMID: 24613021

73. Magro F, Peyrin-Biroulet L, Sokol H, Aldeger X, Costa A, Higgins $\mathrm{PD}$, et al. Extra-intestinal malignancies in inflammatory bowel disease: results of the 3 rd ECCO Pathogenesis Scientific Workshop (III). J Crohn's Colitis. 2014;8(1):31-44. https://doi. org/10.1016/j.crohns.2013.04.006 PMID: 23721759

74. Castellsagué X, Iftner T, Roura E, Vidart JA, Kjaer SK, Bosch FX, et al. Prevalence and genotype distribution of human papillomavirus infection of the cervix in Spain: the CLEOPATRE study. J Med Virol. 2012;84(6):947-56. https://doi. org/10.1002/jmv.23282 PMID: 22499018

75. Torné Bladé A, Bayas Rodríguez JM, Castellsagué Piqué X, Castro Sánchez M, García García E, Martínez Escoriza JC, et al. Vacunación frente al cáncer de cérvix en mujeres fuera de los programas de vacunación sistemática, con o sin infección por el virus del papiloma humano o lesión cervical. Encuesta de opinión y recomendaciones. [Vaccination against cervical cancer in women outside of routine vaccination programs, with or without human papillomavirus infection or cervical lesion. Survey of opinion and recommendations]. Prog Obs Ginecol.2012;55(Suppl 1):10-31. https://doi.org/10.1016/ So304-5013(12)73065-0

76. Kocken M, Helmerhorst TJ, Berkhof J, Louwers JA, Nobbenhuis MA, Bais AG, et al. Risk of recurrent high-grade cervical intraepithelial neoplasia after successful treatment: a long-term multi-cohort study. Lancet Oncol. 2011;12(5):44150. https://doi.org/10.1016/S1470-2045(11)70078-X PMID: 21530398

77. Castellsagué $X$, Muñoz N, Pitisuttithum P, Ferris D, Monsonego J, Ault K, et al. End-of-study safety, immunogenicity, and efficacy of quadrivalent HPV (types $6,11,16,18$ ) recombinant vaccine in adult women $24-45$ years of age. $\mathrm{Br}$ J Cancer. 2011;105(1):28-37. https://doi.org/10.1038/bjc.2011.185 PMID: 21629249

78. Skinner SR, Szarewski A, Romanowski B, Garland SM, Lazcano-Ponce E, Salmerón J, et al. VIVIANE Study Group. Efficacy, safety, and immunogenicity of the human papillomavirus 16/18 ASo4-adjuvanted vaccine in women older than 25 years: 4-year interim follow-up of the phase 3 , double-blind, randomised controlled VIVIANE study. Lancet. 2014;384(9961):2213-27. https://doi.org/10.1016/So1406736(14)60920-X PMID: 25189358

79. Joura EA, Garland SM, Paavonen J, Ferris DG, Perez G, Ault KA, et al. Effect of the human papillomavirus (HPV) quadrivalent vaccine in a subgroup of women with cervical and vulvar disease: retrospective pooled analysis of trial data. BMJ. 2012;344:e1401. PMID: 22454089

80. Kang WD, Choi HS, Kim SM. Is vaccination with quadrivalent HPV vaccine after loop electrosurgical excision procedure effective in preventing recurrence in patients with highgrade cervical intraepithelial neoplasia (CIN2-3)? Gynecol Oncol. 2013;130(2):264-8. https://doi.org/10.1016/j. ygyno.2013.04.050 PMID: 23623831

81. Garland SM, Paavonen J, Jaisamrarn U, Naud P, Salmerón J, Chow SN, et al. Prior human papillomavirus-16/18 ASo4 adjuvanted vaccination prevents recurrent high grade cervical intraepithelial neoplasia after definitive surgical therapy: Posthoc analysis from a randomized controlled trial. Int J Cancer. 2016;139(12):2812-26. https://doi.org/10.1002/ijc.30391 PMID: 27541373

82. Dokal I, Vulliamy T. Inherited aplastic anaemias/bone marrow failure syndromes. Blood Rev. 2008;22(3):141-53. https://doi. org/10.1016/j.blre.2007.11.003 PMID: 18164793

83. Leiding JW, Holland SM. Warts and all: human papillomavirus in primary immunodeficiencies. J Allergy Clin Immunol. 2012;130(5):1030-48. https://doi.org/10.1016/j. jaci.2012.07.049 PMID: 23036745

84. Savani BN, Stratton P, Shenoy A, Kozanas E, Goodman S, Barrett AJ. Increased risk of cervical dysplasia in long-term survivors of allogeneic stem cell transplantation--implications for screening and HPV vaccination. Biol Blood Marrow Transplant. 2008;14(9):1072-5. https://doi.org/10.1016/j. bbmt.2008.07.005 PMID: 18721771

85. Ojha RP, Tota JE, Offutt-Powell TN, Klosky JL, Minniear TD, Jackson BE, et al. Human papillomavirus-associated subsequent malignancies among long-term survivors of pediatric and young adult cancers. PLoS One. 2013;8(8):e70349. https://doi.org/10.1371/journal. pone.0070349 PMID: 23940566

86. Katzenellenbogen RA, Carter JJ, Stern JE, Butsch Kovacic MS, Mehta PA, Sauter SL, et al. Skin and mucosal human papillomavirus seroprevalence in persons with Fanconi Anemia. Clin Vaccine Immunol. 2015;22(4):413-20. https://doi. org/10.1128/CVI.00665-14 PMID: 25651924

87. Kroger AT, Atkinson WL, Marcuse EK, Pickering LKAdvisory Committee on Immunization Practices (ACIP) Centers for Disease Control and Prevention (CDC). General recommendations on immunization: recommendations of the Advisory Committee on Immunization Practices (ACIP). MMWR Recomm Rep. 2006;55(RR-15):1-48. PMID: 17136024

88. Handisurya A, Schellenbacher C, Reininger B, Koszik F, Vyhnanek P, Heitger A, et al. A quadrivalent HPV vaccine induces humoral and cellular immune responses in WHIM immunodeficiency syndrome. Vaccine. 2010;28(30):4837-41. https://doi.org/10.1016/j.vaccine.2010.04.057 PMID: 20472031

89. Children's Oncology Group. Long-Term Follow-Up Guidelines for Survivors of Childhood, Adolescent, and Young Adult Cancers - Version 4.0, October2013. [Accessed 3 Jul 2018] Available from: http://www.survivorshipguidelines.org/pdf/ LTFUGuidelines 40.pdf

90. Klosky JL, Foster RH, Hodges J, Peasant C, Gamble H, McDermott MJ, et al. Human papillomavirus vaccination and the primary prevention of cancer: implications for survivors of childhood cancer. Stud Health Technol Inform. 2012;172:33-42. PMID: 22910499

91. Rose B, Wilkins D, Li W, Tran N, Thompson C, Cossart Y, et al. Human papillomavirus in the oral cavity of patients with and without renal transplantation. Transplantation. 2006;82(4):570-3. https://doi.org/10.1097/01. tp.0000231706.79165.e5 PMID: 16926603

92. Reuschenbach M, Tran T, Faulstich F, Hartschuh W, Vinokurova $\mathrm{S}$, Kloor $\mathrm{M}$, et al. High-risk human papillomavirus in nonmelanoma skin lesions from renal allograft recipients and immunocompetent patients. Br J Cancer. 2011;104(8):1334-41. https://doi.org/10.1038/bjc.2011.95 PMID: 21427726

93. Meeuwis KA, Melchers WI, Bouten $\mathrm{H}$, van de Kerkhof PC, Hinten F, Quint WG, et al. Anogenital malignancies in women after renal transplantation over 40 years in a single center. Transplantation. 2012;93(9):914-22. https://doi.org/10.1097/ TP.obo13e318249b13d PMID: 22377788

94. Park ST, Song MJ, Park JS, Hur SY, Lee CW. Incidence and clinicopathologic behavior of uterine cervical carcinoma in renal transplant recipients. World J Surg Oncol. 2011;9(1):72. https://doi.org/10.1186/1477-7819-9-72 PMID: 21752252

95. Patel HS, Silver AR, Levine T, Williams G, Northover JM. Human papillomavirus infection and anal dysplasia in renal transplant recipients. Br J Surg. 2010;97(11):1716-21. https://doi. org/10.1002/bjs.7218 PMID: 20730855

96. Meeuwis KA, Hilbrands LB, IntHout J, Slangen BF, Hendriks IM, Hinten $F$, et al. Cervicovaginal HPV infection in female renal transplant recipients: an observational, self-sampling based, 
cohort study. Am J Transplant. 2015;15(3):723-33. PMID: 25675976

97. Adami J, Gäbel H, Lindelöf B, Ekström K, Rydh B, Glimelius B, et al. Cancer risk following organ transplantation: a nationwide cohort study in Sweden. Br J Cancer. 2003;89(7):1221-7. https://doi.org/10.1038/sj.bjc.6601219 PMID: 14520450

98. Meeuwis KA, van Rossum MM, van de Kerkhof PC, Hoitsma AJ, Massuger LF, de Hullu JA. Skin cancer and (pre)malignancies of the female genital tract in renal transplant recipients. Transpl Int. 2010;23(2):191-9. https://doi.org/10.1111/j.14322277.2009.00975.x PMID: 19793075

99. Kolb HJ, Socié G, Duell T, Van Lint MT, Tichelli A, Apperley JF, et al. Malignant neoplasms in long-term survivors of bone marrow transplantation. Ann Intern Med. 1999;131(10):738-44. https://doi.org/10.7326/0003-4819-131-10-199911160-00004 PMID: 10577296

100. Bhatia S, Louie AD, Bhatia R, O’Donnell MR, Fung H, Kashyap $A$, et al. Solid cancers after bone marrow transplantation. J Clin Oncol. 2001;19(2):464-71. https://doi.org/10.1200/ JCO.2001.19.2.464 PMID: 11208840

101. Rizzo JD, Curtis RE, Socié G, Sobocinski KA, Gilbert $\mathrm{E}$, Landgren $\mathrm{O}$, et al. Solid cancers after allogeneic hematopoietic cell transplantation. Blood. 2009;113(5):1175 83. https://doi.org/10.1182/blood-2008-05-158782 PMID: 18971419

102. Savani BN, Goodman S, Barrett AJ. Can routine posttransplant HPV vaccination prevent commonly occurring epithelial cancers after allogeneic stem cell transplantation? Clin Cancer Res. 2009;15(7):2219-21. https://doi.org/10.1158/1078-0432. CCR-08-3099 PMID: 19293253

103. Wang Y, Brinch L, Jebsen P, Tanbo T, Kirschner R. A clinical study of cervical dysplasia in long-term survivors of allogeneic stem cell transplantation. Biol Blood Marrow Transplant. 2012;18(5):747-53. https://doi.org/10.1016/j. bbmt.2011.09.012 PMID: 21963879

104. Kumar D, Unger ER, Panicker G, Medvedev P, Wilson L, Humar A. Immunogenicity of quadrivalent human papillomavirus vaccine in organ transplant recipients. Am J Transplant. 2013;13(9):2411-7. https://doi.org/10.1111/ajt.12329 PMID: 23837399

105. Gomez-Lobo V, Whyte T, Kaufman S, Torres C, Moudgil A. Immunogenicity of a prophylactic quadrivalent human papillomavirus L1 virus-like particle vaccine in male and female adolescent transplant recipients. Pediatr Transplant. 2014;18(3):310-5. https://doi.org/10.1111/petr.12226 PMID: 24484551

106. Nelson DR, Neu AM, Abraham A, Amaral S, Batisky D, Fadrowski JJ. Immunogenicity of Human Papillomavirus Recombinant Vaccine in Children with CKD. Clin J Am Soc Nephrol. 2016;11(5):776-84. https://doi.org/10.2215/ CJN.09690915 PMID: 27055465

107.Palefsky JM, Gillison ML, Strickler HD. Chapter 16: HPV vaccines in immunocompromised women and men. Vaccine. 2006;24 Suppl 3:S3/140-6.

108. Reusser NM, Downing C, Guidry J, Tyring SK. HPV Carcinomas in Immunocompromised Patients. J Clin Med. 2015;4(2):26081. https://doi.org/10.3390/jcm4020260 PMID: 26239127

109. Grein IH, Groot N, Lacerda MI, Wulffraat N, Pileggi G. HPV infection and vaccination in Systemic Lupus Erythematosus patients: what we really should know. Pediatr Rheumatol Online J. 2016;14(1):12. https://doi.org/10.1186/s12969-0160072-x PMID: 26956735

110.Santana IU, Gomes AN, Lyrio LD, Rios Grassi MF, Santiago MB. Systemic lupus erythematosus, human papillomavirus infection, cervical pre-malignant and malignant lesions: a systematic review. Clin Rheumatol. 2011;30(5):665-72. https:// doi.org/10.1007/s10067-010-1606-0 PMID: 21072553

111. Zard E, Arnaud L, Mathian A, Chakhtoura Z, Hie M, Touraine $P$, et al. Increased risk of high grade cervical squamous intraepithelial lesions in systemic lupus erythematosus: A meta-analysis of the literature. Autoimmun Rev. 2014;13(7):730-5. https://doi.org/10.1016/j. autrev.2014.03.001 PMID: 24657969

112.Lyrio LD, Grassi MF, Santana IU, Olavarria VG, Gomes AN, CostaPinto L, et al. Prevalence of cervical human papillomavirus infection in women with systemic lupus erythematosus. Rheumatol Int. 2013;33(2):335-40. https://doi. org/10.1007/s00296-012-2426-0 PMID: 22451033

113. Adams DR, Zaenglein AL, Hershey MS. Etanercept and warts. Drugs Dermatol. 2004;3(6):601. PMID: 15624740

114. Kim SY, Solomon DH. Tumor necrosis factor blockade and the risk of viral infection. Nat Rev Rheumatol. 2010;6(3):165-74. https://doi.org/10.1038/nrrheum.2009.279 PMID: 20142812

115. Mok CC, Ho LY, Fong LS, To CH. Immunogenicity and safety of a quadrivalent human papillomavirus vaccine in patients with systemic lupus erythematosus: a case-control study. Ann Rheum Dis. 2013;72(5):659-64. https://doi.org/10.1136/ annrheumdis-2012-201393 PMID: 22589375

116. Heijstek MW, Scherpenisse M, Groot N, Wulffraat NM, Van Der Klis FR. Immunogenicity of the bivalent human papillomavirus vaccine in adolescents with juvenile systemic lupus erythematosus or juvenile dermatomyositis. J Rheumatol. 2013;40(9):1626-7. https://doi.org/10.3899/jrheum.130246 PMID: 23997002

117. Soybilgic A, Onel KB, Utset T, Alexander K, Wagner-Weiner L. Safety and immunogenicity of the quadrivalent HPV vaccine in female Systemic Lupus Erythematosus patients aged 12 to 26 years. Pediatr Rheumatol Online J. 2013;11(1):29. https://doi. org/10.1186/1546-0096-11-29 PMID: 23924237

118. Heijstek MW, Scherpenisse M, Groot N, Tacke C, Schepp RM, Buisman AM, et al. Immunogenicity and safety of the bivalent HPV vaccine in female patients with juvenile idiopathic arthritis: a prospective controlled observational cohort study. Ann Rheum Dis. 2014;73(8):1500-7. https://doi.org/10.1136/ annrheumdis-2013-203429 PMID: 23723319

119. Esposito S, Corona F, Barzon L, Cuoco F, Squarzon L, Marcati $\mathrm{G}$, et al. Immunogenicity, safety and tolerability of a bivalent human papillomavirus vaccine in adolescents with juvenile idiopathic arthritis. Expert Rev Vaccines. 2014;13(11):138793. https://doi.org/10.1586/14760584.2014.943195 PMID: 25066387

120. van Assen S, Agmon-Levin N, Elkayam O, Cervera R, Doran MF, Dougados $M$, et al. EULAR recommendations for vaccination in adult patients with autoimmune inflammatory rheumatic diseases. Ann Rheum Dis. 2011;70(3):414-22. https://doi. org/10.1136/ard.2010.137216 PMID: 21131643

121. Carifi M, Napolitano D, Morandi M, Dall'Olio D. Recurrent respiratory papillomatosis: current and future perspectives. Ther Clin Risk Manag. 2015;11:731-8. https://doi.org/10.2147/ TCRM.S81825 PMID: 25999724

122. Chirilă M, Bolboacă SD. Clinical efficiency of quadrivalent HPV (types 6/11/16/18) vaccine in patients with recurrent respiratory papillomatosis. Eur Arch Otorhinolaryngol. 2014;271(5):1135-42. https://doi.org/10.1007/s00405-0132755-y PMID: 24121781

123. Lindeberg H, Elbrønd O. Laryngeal papillomas: the epidemiology in a Danish subpopulation 1965-1984. Clin Otolaryngol Allied Sci. 1990;15(2):125-31. https://doi. org/10.1111/j.1365-2273.1990.tbo0444.x PMID: 2350888

124. Derkay CS. Task force on recurrent respiratory papillomas. A preliminary report. Arch Otolaryngol Head Neck Surg. 1995;121(12):1386-91. https://doi.org/10.1001/ archotol.1995.01890120044008 PMID: 7488368

125. Förster G, Boltze C, Seidel J, Pawlita M, Müller A. [Juvenile laryngeal papillomatosis--immunisation with the polyvalent vaccine gardasil]. Laryngorhinootologie. 2008;87(11):796-9. PMID: 18759217

126. Young DL, Moore MM, Halstead LA. The use of the quadrivalent human papillomavirus vaccine (gardasil) as adjuvant therapy in the treatment of recurrent respiratory papilloma. J Voice. 2015;29(2):223-9. https://doi. org/10.1016/j.jvoice.2014.08.003 PMID: 25619468

127. Mudry P, Vavrina M, Mazanek P, Machalova M, Litzman J, Sterba J. Recurrent laryngeal papillomatosis: successful treatment with human papillomavirus vaccination. Arch Dis Child. 2011;96(5):476-7. https://doi.org/10.1136/ adc.2010.198184 PMID: 21220258

128. Mészner Z, Jankovics I, Nagy A, Gerlinger I, Katona G. Recurrent laryngeal papillomatosis with oesophageal involvement in a 2 year old boy: successful treatment with the quadrivalent human papillomatosis vaccine. Int Pediatr Otorhinolaryngol. 2015;79(2):262-6. https://doi. org/10.1016/j.ijporl.2014.11.022 PMID: 25496821

129. Yi L, Vaudaux B, Sandu K, Nisa L. Prolonged remission of juvenile-onset respiratory papillomatosis: a postexpositional role of the tetravalent anti-HPV vaccine? Int J Pediatr Otorhinolaryngol. 2014;78(2):388-90. https://doi. org/10.1016/j.ijporl.2013.12.013 PMID: 24388316

130. Hočevar-Boltežar I, Matičič M, Sereg-Bahar M, Gale N, Poljak $M$, Kocjan $B$, et al. Human papilloma virus vaccination in patients with an aggressive course of recurrent respiratory papillomatosis. Eur Arch Otorhinolaryngol. 2014;271(12):325562. https://doi.org/10.1007/s00405-014-3143-y PMID: 24964770

131. Hermann JS, Weckx LY, Monteiro Nürmberger J, Santos Junior GF, Campos Pignatari AC, Nagata Pignatari SS. Effectiveness of the human papillomavirus (types $6,11,16$, and 18) vaccine in the treatment of children with recurrent respiratory papillomatosis. Int J Pediatr Otorhinolaryngol. 2016;83:94-8. https://doi.org/10.1016/j.ijporl.2016.01.032 PMID: 26968061 
132. Pawlita M, Gissmann L. Rekurrierende respiratorische

Papillomatose [Recurrent respiratory papillomatosis]. Dtsch Med Wochenschr. 2009;134:S100-S102. PMID: 19353471

\section{License and copyright}

This is an open-access article distributed under the terms of the Creative Commons Attribution (CC BY 4.0) Licence. You may share and adapt the material, but must give appropriate credit to the source, provide a link to the licence, and indicate if changes were made.

This article is copyright of the authors or their affiliated institutions, 2019. 